\title{
Correlation between antioxidant activity and anti-wrinkle effect of ethanol extracts of Sanguisorba Officinalis L.
}

\author{
Na-Young BYUN ${ }^{1 ¥}$, Joong-Hyun $\mathrm{CHO}^{2 \ddagger}$, Soon-Ho $\mathrm{YIM}^{1 *}$
}

\begin{abstract}
Sanguisorba officinalis L., the dried roots of which are referred to as cucumber herb is a perennial herb belonging to the family Rosaceae. This study was showed the correlation between the antioxidant activity and its anti-wrinkle effects of ethanol extraction concentration of $S$. officinalis $\mathrm{L}$. The extraction yield of the S. officinalis extracts was all $10 \%$ or more, which was judged to be economical. $80 \%$ ethanol extracts was the highest in total polyphenol and flavonoid contents and the best total antioxidant activity. The correlation between total polyphenol and flavonoid contents and antioxidant activity was 0.830 and 0.872 , respectively, with a significant correlation was confirmed. In addition, in $80 \%$ ethanol extracts, superoxide anion and NO radical scavenging activities were the most effective. These results validated that the optimum extraction concentration for S. officinalis was $80 \%$ ethanol.
\end{abstract}

Keyword: Sanguisorba officinalis L.; ethanol extracts; antioxidant; anti-wrinkle; correlation.

Practical Application: Research about antioxidant activities and anti-wrinkling functional products of Sanguisorba officinalis $\mathrm{L}$.

\section{Introduction}

The human body constantly needs oxygen when it gets the energy. About 2 to $3 \%$ of the oxygen inhaled during respiration is converted to toxic substances called free radicals, causing cell damage (Cho et al., 2008). Reactive Oxygen Species (ROS), hydroxyl radical, hydrogen peroxide and Superoxide anion etc., leads to DNA denaturation, lipid peroxidation, protein inactivation, and other cell dysfunctions. These cause the cancers, diabetes, atherosclerosis and Parkinson's disease (Halliwell et al., 1992; Thannickal \& Fanburg, 2000). ROS and Reactive Nitrogen Species (RNS), which are directly responsible for oxidative stress, are unstable and highly reactive. Furthermore, these are easily reacted with biomaterials and attacked biomolecules, caused damage to cells and tissues (Lee \& Im, 2012). In particular, ROS, was produced by free Radicals $\left(\mathrm{NO}^{-}, \mathrm{OH}^{-}, \mathrm{O}_{2}^{-}\right)$, causes aging, inflammation, carcinogenesis, and atherosclerosis (Cho et al., 2008). The human body has biological defense systems such as superoxide dismutase (SOD), glutathione peroxidase (GSH-Px), catalase (CAT), glutathione (GSH) and glutathione S-transferase (GST) to remove these free radicals (Kil et al., 2015).

It is being actively explored research about synthetic or natural antioxidants that eliminate ROS and increase antioxidant defense systems in human body (Kim et al., 2009). Highly reactive antioxidants remove harmful substances in the body, protect cells by preventing chain reactions caused by free radicals and prevent apoptosis of cells (Kil et al., 2015). Antioxidants can be classified as water-soluble antioxidants (glutathione, vitamin C, uric acid, etc.), fat-soluble antioxidants (flavonoid, tocopherol, carotenoids, etc.), synthetic antioxidants (tert-butylhydroxyanisole (BHA), tert-butylhydroxytoluene (BHT), etc.), and antioxidant enzyme (catalase, superoxide dismutase (SOD), glutathione peroxidase, etc.). Antioxidants can protect cells from oxidative damage by removing free radicals intermediates and prevent cell apoptosis (Lim, 2010). Synthetic antioxidants such as BHA and BHT have excellent antioxidant effects, however, showed various side effects caused by toxicity; thus, there is increasing interest in research on safe natural antioxidants (Park et al., 2012a).

Sanguisorba officinalis Linne. (S. officinalis L.) is a species of rose family, widely distributed throughout China, Japan, and Korea, and especially grows in places with moderate moisture on mountain slopes. It is a slightly curved spindle shape, $10-20 \mathrm{~cm}$ long and 5-20 $\mathrm{mm}$ in diameter. It has cold properties, tastes bitter and sour, and is non-toxic and fragrance-free (Kim et al., 2011). It has been mainly used in wound treatment and hemostasis in oriental medicine, and is known to be effectual in dermatitis, mucosal inflammation, eczema, and burns (Park et al., 2012b). The main ingredients are ziguglycoside I, II, pomlic acid, gallic acid, ellagic acid, and quercethin at the root; quercetin, kaempferol, ursolic acid, saponinat branches; vit C in leaf; chrysanthemin, cyanin in flower (Jang et al., 2013).

In this study, we extracted S. officinalis L. by various ethanol concentrations and investigated total polyphenol contents, total flavonoid contents, antioxidative activity, active nitrogen evaluation. In addition, we evaluated the ability to improvewrinkle with various in vitro models and identified the correlation between antioxidant capacity and wrinkle improvement. Furthermore, 
we intend to provide basic data to ascertain the availability of S. officinalis $\mathrm{L}$. as a natural antioxidant material.

\section{Materials and methods}

\subsection{Experimental materials}

S. officinalis L. roots were purchased from Geohub (Yangju, Gyeonggi-do, Korea). Folin-Ciocalteu reagent, ABTS (2,2'-azinobis-3-ethylbenzothiazoline-6-sulfonic acid), DPPH (1,1-diphenyl2-picrylhydrazyl), Trolox, and L-ascorbic acid were purchased from Sigma-Aldrich Co. (St. Louis, MO, USA). The solvents and all reagents used special-grade reagents.

\subsection{Sample extraction}

Samples $(10 \mathrm{~g})$ pulverized with a grinder (NFM-3561SN, NUC Co., Daegu, Korea) were reflux extracted with $100 \mathrm{~mL}$ of distilled water, $20 \%$ ethanol, $40 \%$ ethanol, $80 \%$ ethanol, and $100 \%$ ethanol for $60 \mathrm{~min}$ at $100^{\circ} \mathrm{C}$ and filtered. SpeedVac (COSMOS 660-50L, Kyungseo Machines Co., Incheon, Korea) was used to concentrate and obtain yields. The concentrated sample was stored at $4{ }^{\circ} \mathrm{C}$ before use.

\subsection{Total Phenolic Contents (TPC) and Total Flavonoid Contents (TFC)}

Total polyphenol contents was measured using the Folin-Ciocalteu colorimetric method (Yun et al., 2018) and gallic acid was used as a standard solution. Each extracts $(500 \mu \mathrm{L})$ was added to Folin-Coicalteu reagent $(500 \mu \mathrm{L})$ for $3 \mathrm{~min}$ at room temperature, reacted to $500 \mu \mathrm{L}$ of $10 \% \mathrm{Na}_{2} \mathrm{CO}_{3}$ for 1 hour, block the light, and then measured at $760 \mathrm{~nm}$ with an UV/VIS spectrophotometer (Neogen, Optizen 2120 UV, Sejong, Korea). TPC (mg GAE/g) standard curve was obtainedwith gallic acid $\left(y=0.0378 x+0.3719, R^{2}=0.997\right)$.

Total flavonoid contents were determined using the Moreno method (Moreno et al., 2000), and catechin was used as a standard solution. Each sample was mixed with $5 \% \mathrm{NaNO}_{2}$ for $5 \mathrm{~min}$ at room temperature, then added $10 \% \mathrm{AlCl}_{3}$ for $5 \mathrm{~min}$ at room temperature. After adding $1 \mathrm{~N} \mathrm{NaOH}$, absorbance was measured at $415 \mathrm{~nm}$ using a spectrophotometer (Mecasys Co., Daejeon, Korea). TFC (mg CE/g) standard curve was obtained with catechin $\left(y=0.0025 x+0.0142, R^{2}=0.999\right)$.

\subsection{Antioxidant activity}

Phosphomolybdenum antioxidant assay (Total Antioxidant Capacity, TAC)

The total antioxidant activity was evaluated by phosphomolybdenum antioxidant assay as described by Prieto et al. (1999). Each sample was mixed with reagent solution (0.6 M sulfuric acid, $28 \mathrm{mM}$ sodium phosphate, $4 \mathrm{mM}$ ammonium molybdate) at $90^{\circ} \mathrm{C}$ for $90 \mathrm{~min}$. After cooling to room temperature, the absorbance was measured at $695 \mathrm{~nm}$ using an UV/VIS spectrophotometer (Neogen, Optizen 2120 UV, Sejong, Korea). The total antioxidant activity (mg AAE/g) standard curve was obtained with L-ascorbic acid $\left(\mathrm{y}=0.0021 \mathrm{x}-0.0165, \mathrm{R}^{2}=0.991\right)$.

\section{Ferric-Reducing Antioxidant Power (FRAP)}

The ferric-reducing antioxidant power activity was measured by modifying method of Benzie \& Strain (1996). Each sample was mixed with FRAP solution $(300 \mathrm{mM}$ acetate buffer (pH 3.6), $10 \mathrm{mM}$ 2,4,6-tripyridyl-s-triazine (TPTZ), and $20 \mathrm{mM} \mathrm{FeCl} \cdot 6 \mathrm{H}_{2} \mathrm{O}$ ) at $37^{\circ} \mathrm{C}$ for $30 \mathrm{~min}$, and then was measured an UV/VIS spectrophotometer (Neogen, Optizen 2120 UV, Sejong, Korea) at $595 \mathrm{~nm}$. The FRAP (mg TE/g) standard curve was obtained with Trolox $\left(y=0.0021 x-0.0165, R^{2}=0.991\right)$.

\subsection{Free radical scavenging activity assay}

\section{$D P P H$ radical scavenging activity}

DPPH radical scavenging activity was measured by applying the experimental methods of Yamaguchi et al. (1998). The sample solution were added $0.2 \mathrm{mM} \mathrm{DPPH}(190 \mu \mathrm{L})$ at room temperature for $30 \mathrm{~min}$, and measured at $515 \mathrm{~nm}$ using an ELISA reader (Thermo Fisher SCIENTIFIC, Multiskan Sky, Korea). The DPPH radical scavenging activity (mg TE/g) standard curve was obtained with Trolox $\left(y=0.0015 x+2.3996, R^{2}=0.997\right)$.

\section{ABTS radical scavenging activity}

ABTS radical scavenging activity was measured by applying the experimental method of Thaipong et al. (2006). A solution of $7.4 \mathrm{mM} \mathrm{ABTS}$ and $2.45 \mathrm{mM}$ potassium persulfate was mixed at $37^{\circ} \mathrm{C}$ for $24 \mathrm{~h}$. Each sample and ABTS solution was reacted in the dark room for $5 \mathrm{~min}$, and measured the UV/VIS spectrophotometer (Neogen, Optizen 2120 UV, Sejong, Korea) at $734 \mathrm{~nm}$. The ABTS radical scavenging activity $(\mathrm{mg} \mathrm{TE} / \mathrm{g})$ standard curve was obtained with Trolox $(y=0.0001 x+0.9179$, $\left.\mathrm{R}^{2}=0.996\right)$.

\section{Superoxide Anion Radical Scavenging Activity (SRSA)}

Superoxide anion radical scavenging activity (SRSA) was measured by the nitroblue tetrazolium (NBT) reduction (Fridovich, 1970). Each sample was reacted with SASA solution (0.1 M phosphate buffer ( $\mathrm{pH} 8.0), 0.05 \mathrm{U} / \mathrm{mL}$ xanthine oxidase, and substrate ( $0.4 \mathrm{mM}$ xanthine, $0.24 \mathrm{mM}$ nitroblue tetrazolium)) in the dark room at $37^{\circ} \mathrm{C}$. Then, the absorbance was measured at $510 \mathrm{~nm}$. SRSA was calculated using the following equation: SRSA $(\%)=(A-B) / A \times 100$, where $A$ is the absorbance of the control and $B$ is the absorbance of the test sample.

\section{Nitric Oxide radical (NO.) scavenging activity}

Nitric oxide radical scavenging activity was measured using the method of Nagata et al. (1999). Each sample was mixed with $50 \mathrm{mM}$ phosphate buffer ( $\mathrm{pH}$ 7.4), $40 \mathrm{mM}$ soudium nitroprusside (SNP), and 4,5-Diaminofluorescein (DAF-2) in dimethyl Sulfoxide for at room temperature for $10 \mathrm{~min}$, measured using a fluorescence microplate reader (Spectra Max Gemini EM, Molecular Devices Corp., USA) at excitation $485 \mathrm{~nm}$ and emission $525 \mathrm{~nm}$. Nitric oxide radical scavenging activity (\%) $=(\mathrm{A}-\mathrm{B}) / \mathrm{A} \times 100$, where $\mathrm{A}$ is the fluorescence intensity of the control and $B$ is the fluorescence intensity of the test sample. 


\subsection{Anti-wrinkling assay}

\section{Collagenase inhibition assay}

The collagenase inhibitory effect was measured using Wünsch \& Heidrich (1963) method. The substrate solution was prepared with $4 \mathrm{mM} \mathrm{CaCl}_{2}$ and $0.3 \mathrm{mg} / \mathrm{mL}$ of 4-phenylazobenzyloxycarbonylPro-Leu-Gly-Pro-D-Arg in 0.1 M Tris-HCl buffer ( $\mathrm{pH}$ 7.5). Each sample were mixed with substrate solution and collagenase at $37^{\circ} \mathrm{C}$ for $20 \mathrm{~min}$ and measured by UV/VIS spectrophotometer at $320 \mathrm{~nm}$. Collagenase inhibition was calculated using the following equation: collagenase inhibition $(\%)=(\mathrm{A}-\mathrm{B}) / \mathrm{A} \times 100$, where $\mathrm{A}$ is the absorbance of the control, Epigallocatechin gallate (EGCG) and B is the absorbance of the test sample.

\section{Elastase enzyme inhibition assay}

The effect of elastase inhibitory activity was measured by Kraunsoe et al. (1996) modifying method. Each sample was added the reaction mixture containing $3.2 \mathrm{mM} \mathrm{N}$-succinyl-(Ala) ${ }_{3}-p$ nitroanilide and $2.8 \times 10^{-3}$ unit porcine pancreas elastase in $0.2 \mathrm{M}$ Tris- $\mathrm{HCl}$ buffer ( $\mathrm{pH} \mathrm{8.0)}$ ) at $37^{\circ} \mathrm{C}$ for $30 \mathrm{~min}$ and measured at $410 \mathrm{~nm}$. Elastase inhibitory activity $(\%)=(\mathrm{A}-\mathrm{B}) / \mathrm{A} \times 100$, where $\mathrm{A}$ is the absorbance of the control (distilled water) and $\mathrm{B}$ is the absorbance of the test sample.

\subsection{Statistical analysis}

Experimental data of this study are expressed as mean \pm standard deviation after three times experiments of each sample. Statistical analysis was performed using the Statistical Package for the Social Sciences (SPSS), and one-way analysis of variance (ANOVA) was performed to test the statistical significance between each experimental group. In cases where differences were observed, Tukey's test was conducted post-test, with $p<0.05$ considered statistically significant. The correlation was indicated by Pearson's correlation coefficient.

\section{Results and discussion}

\subsection{Extraction yield}

Even if their excellent physiological activity, lower extracts yield is less economic feasibility. Extracts yield is an important factor to be considered in the various commercialization of functional extracts (Kim et al., 2019). After concentrating the extracts, the extraction yield was calculated. The highest extraction yields were $80 \%$ and $100 \%$ ethanol extracts $(26.50 \%)$, and $20 \%$ ethanol extracts (13.37\%) showed the lowest yield. The difference in extraction yields is thought to be due to the ratio of ethanol to water. If the extraction yield exceeds $10 \%$ in natural products, it is known to be economic feasibility (Park et al., 2003), so all extracts of $S$. officinalisare considered a commercially available plant material.

\subsection{Total Phenolic Contents (TPC) and Total Flavonoid Contents (TFC)}

Many hydroxyl groups (-OH) in polyphenols are easily bonded to various compounds, so they have excellent antioxidant, anti-cancer, and anti-inflammatory effects (Kim et al., 2012).
The highest total polyphenol content was in the $40 \%$ ethanol extracts and the $80 \%$ ethanol extracts at $121.96 \pm 0.0 \mathrm{mg} \mathrm{GAE} / \mathrm{g}$, followed by the $100 \%$ ethanol extracts ( $108.02 \pm 0.42 \mathrm{mg} \mathrm{GAE} / \mathrm{g})$, $20 \%$ ethanol extracts $(76.56 \pm 0.48 \mathrm{mg} \mathrm{GAE} / \mathrm{g})$, and distilled water extracts $(59.29 \pm 0.49 \mathrm{mg} \mathrm{GAE} / \mathrm{g})$ in that order, with a significant difference by Tukey's multiple range test at $\mathrm{p}<0.05$ (Table 1).

Flavonoids are known to have high antioxidant activity by effectively removing ROS. Like polyphenols, they are known to have anti-inflammatory, anticancer, and antiviral effects (Kim et al., 2012). In addition, flavonoids are also widely present in the plant system and are contained in all parts of the plant (Ham et al., 2018). Flavonoid contents showed the highest value of $101.19 \pm 2.87 \mathrm{mg} \mathrm{CE} / \mathrm{g}$ in the $80 \%$ ethanol extracts, followed by the $100 \%$ ethanol extracts $(92.87 \pm 0.64 \mathrm{mg} \mathrm{CE} / \mathrm{g})$, $40 \%$ ethanol extracts $(89.82 \pm 1.42 \mathrm{mg} \mathrm{CE} / \mathrm{g}), 20 \%$ ethanol extracts $(63.20 \pm 0.66 \mathrm{mg} \mathrm{CE} / \mathrm{g})$, and distilled water extracts $(52.37 \pm 2.56 \mathrm{mg} \mathrm{CE} / \mathrm{g})$ in that order, with a significant difference by Tukey's multiple range test at $\mathrm{p}<0.05$ (Table 1 ). From these results, the highest polyphenol and flavonoid contents was found in $80 \%$ ethanol extracts.

\subsection{Antioxidant activity}

\section{Total antioxidant capacity}

The total antioxidant capacity experiment is based on the reduction of $\mathrm{Mo}(\mathrm{VI})-\mathrm{Mo}(\mathrm{V})$ by the extracts and the subsequent formation of the green phosphate/Mo (V) complex at acidic $\mathrm{pH}$ (Saha et al., 2008). The best TAC was $80 \%$ ethanol extracts $(34.66 \pm 2.89 \mathrm{mg} \mathrm{AAE} / \mathrm{g})$, followed by $100 \%$ ethanol extracts (28.04 $\pm 0.39 \mathrm{mg} \mathrm{AAE} / \mathrm{g})$, and $40 \%$ ethanol extracts (28.04 \pm 0.62$)$, $20 \%$ ethanol extracts $(18.83 \pm 0.18 \mathrm{mg} \mathrm{AAE} / \mathrm{g})$, and distilled water extracts $(16.34 \pm 2.00 \mathrm{mg} \mathrm{AAE} / \mathrm{g})$, in that order (Table 2).

\section{Ferric-reducing antioxidant power}

FRAP can be measure the reducing power by measuring the blue wavelength at $593 \mathrm{~nm}$ that occurs when $\mathrm{Fe}^{3+}$ is reduced to $\mathrm{Fe}^{2+}$ (Lee et al., 2012; Ku et al., 2009). In this study, the $40 \%$ ethanol extracts showed the highest reducing power at $609.85 \pm 5.25 \mathrm{mg} \mathrm{TE} / \mathrm{g}$ followed by $80 \%$ ethanol extracts $(565.13 \pm 5.54 \mathrm{mg} \mathrm{TE} / \mathrm{g})$, and $100 \%$ ethanol extracts $(543.86 \pm 5.22 \mathrm{mg} \mathrm{TE} / \mathrm{g}), 20 \%$ ethanol extracts $(380.54 \pm 3.36 \mathrm{mg} \mathrm{TE} / \mathrm{g})$, and distilled water extracts $(331.50 \pm 2.97 \mathrm{mg} \mathrm{TE} / \mathrm{g})$ in that order, with a significant difference

Table 1. Total polyphenol contents and total flavonoid contents in water and ethanol extracts of Sanguisorba officinalis L.

\begin{tabular}{|c|c|c|}
\hline Sample & $\begin{array}{c}\text { Total polyphenols } \\
\text { contents } \\
\left(\mathrm{mg} \mathrm{GAE} / \mathrm{g}^{1)}\right)\end{array}$ & $\begin{array}{c}\text { Total Flavonoid } \\
\text { contents } \\
\left(\mathrm{mg} \mathrm{CE} / \mathrm{g}^{2)}\right) \\
\end{array}$ \\
\hline D.W & $59.29 \pm 0.49^{\mathrm{a} 334)}$ & $52.37 \pm 2.56^{\mathrm{a}}$ \\
\hline $20 \% \mathrm{EtOH}$ & $76.56 \pm 0.48^{\mathrm{b}}$ & $63.20 \pm 0.66^{\mathrm{b}}$ \\
\hline $40 \% \mathrm{EtOH}$ & $121.96 \pm 0.00^{\mathrm{d}}$ & $89.82 \pm 1.42^{c}$ \\
\hline $80 \% \mathrm{EtOH}$ & $121.96 \pm 0.00^{\mathrm{d}}$ & $101.19 \pm 2.87^{\mathrm{d}}$ \\
\hline $100 \% \mathrm{EtOH}$ & $108.02 \pm 0.42^{c}$ & $92.87 \pm 0.64^{c}$ \\
\hline
\end{tabular}

${ }^{1)}$ Gallic acid equivalent; ${ }^{2)}$ Catechin equivalent; ${ }^{3)}$ Values are mean \pm standard deviation $(\mathrm{n}=3) ;{ }^{4}$ Values with different letters within the same row are significantly different by Tukey's multiple range test at $\mathrm{p}<0.05$. 
Antioxidant activities and anti-wrinkling effect of sanguisorba officinalis 1.

Table 2. Measurement of antioxidant activity of water and ethanol extracts of Sanguisorba officinalis L.

\begin{tabular}{cccccc}
\hline Sample & $\begin{array}{c}\text { TAC } \text { assay }^{1)} \\
\left(\mathrm{mg} \mathrm{AAE} / \mathrm{g}^{3)}\right)\end{array}$ & $\begin{array}{c}\text { FRAP assay }^{2)} \\
\left(\mathrm{mg} \mathrm{TE} / \mathrm{g}^{4}\right)\end{array}$ & $\begin{array}{c}\text { DPPH } \\
(\mathrm{mg} \mathrm{TE} / \mathrm{g})\end{array}$ & $\begin{array}{c}\text { ABTS } \\
(\mathrm{mg} \mathrm{TE} / \mathrm{g})\end{array}$ & $\begin{array}{c}\text { SRSA }^{5)} \\
\text { RC }\end{array}$ \\
\hline D.W & $16.34 \pm 2.00^{\mathrm{ab}) 7)}$ & $331.50 \pm 2.97^{\mathrm{a}}$ & $1,325.18 \pm 1.04^{\mathrm{b}}$ & $10,279.00 \pm 0.00^{\mathrm{d}}$ & $90.25 \pm 0.68^{\mathrm{a}}$ \\
$20 \% \mathrm{EtOH}$ & $18.83 \pm 0.18^{\mathrm{a}}$ & $380.54 \pm 3.36^{\mathrm{b}}$ & $1,338.62 \pm 0.31^{\mathrm{d}}$ & $10,165.67 \pm 3.33^{\mathrm{c}}$ & $88.44 \pm 7.69^{\mathrm{a}}$ \\
$40 \% \mathrm{EtOH}$ & $28.04 \pm 0.62^{\mathrm{b}}$ & $609.85 \pm 5.25^{\mathrm{e}}$ & $1,305.18 \pm 0.29^{\mathrm{a}}$ & $10,869.00 \pm 0.00^{\mathrm{e}}$ & $73.90 \pm 6.31^{\mathrm{a}}$ \\
$80 \% \mathrm{EtOH}$ & $34.66 \pm 2.89^{\mathrm{b}}$ & $565.13 \pm 5.54^{\mathrm{d}}$ & $1,333.40 \pm 0.21^{\mathrm{c}}$ & $9,845.67 \pm 3.33^{\mathrm{b}}$ & $70.89 \pm 24.41^{\mathrm{a}}$ \\
$100 \% \mathrm{EtOH}$ & $28.04 \pm 0.39^{\mathrm{b}}$ & $543.86 \pm 5.22^{\mathrm{c}}$ & $1,400.40 \pm 0.24^{\mathrm{e}}$ & $9,529.00 \pm 5.77^{\mathrm{a}}$ & $87.19 \pm 1.37^{\mathrm{a}}$ \\
\hline
\end{tabular}

${ }^{1)}$ Total antioxidant capacity; ${ }^{2)}$ Ferric-reducing antioxidant power; ${ }^{3)}$ Ascorbic acid equivalent; ${ }^{4)}$ Trolox equivalent; ${ }^{5}$ Superoxide anion radical scavenging activity; ${ }^{6)}$ Values are mean \pm standard deviation $(n=3) ;{ }^{7}$ Values with different letters within the same row are significantly different by Tukey's multiple range test at $\mathrm{p}<0.05$.

(Table 2). These results showed that the $40 \%$ ethanol extracts had the highest reducing power when $\mathrm{Fe}^{3+}$ was reduced to $\mathrm{Fe}^{2+}$.

\subsection{Free radical scavenging activity assay}

\section{$D P P H$ radical scavenging activity}

DPPH is reduced in the presence of antioxidants to changes in color from deep purple to loss of color (Choi et al., 2003). The $100 \%$ ethanol extracts was the highest at $1,400.40 \pm 0.24 \mathrm{mg}$ $\mathrm{TE} / \mathrm{g}$, and the others were showed similar activity, at $1,300.00 \mathrm{mg}$ $\mathrm{TE} / \mathrm{g}$ or more (Table 2$)$. Compared to ascorbic acid $(100 \mu \mathrm{g} / \mathrm{mL})$, which is used as a positive control, the activities of the all extracts of S. officinalis have been shown to be significantly better. These results confirmed that DPPH radical scavenging activity was the best in $100 \%$ ethanol extracts.

\section{ABTS radical scavenging activity}

When ABTS and potassium persulfate are reacted in a dark place, ABTS ${ }^{+}$is produced. This reacts with the antioxidants and the cations are eliminated. It is decolorized and its antioxidant capacity can be measured by its absorbance (Boo et al., 2009). The $40 \%$ ethanol extracts showed the highest ABTS activity at 10,869.00 $\pm 0.00 \mathrm{mg} \mathrm{TE} / \mathrm{g}$, followed by distilled water extracts $(10,279.00 \pm 0.00 \mathrm{mg}$ TE/g), $20 \%$ ethanol extracts $(10,165.67 \pm 3.33 \mathrm{mg} \mathrm{TE} / \mathrm{g}), 80 \%$ ethanol extracts $(9,845.67 \pm 3.33 \mathrm{mg} \mathrm{TE} / \mathrm{g})$, and $100 \%$ ethanol extracts $(9,529.00 \pm 5.77 \mathrm{mg} \mathrm{TE} / \mathrm{g})$ in that order (Table 2).

\section{Superoxide anion radical scavenging activity}

It is known that about 0.4 to $4 \%$ of the total consumed oxygen is converted into free radicals and superoxides during the normal oxidative phosphorylation process. Also the generated superoxide is known to be converted to other ROS, causing cell damage either directly or indirectly (Kim et al., 2009). The antioxidant effect of the extracts was confirmed through the ability to remove superoxide radiation directly. The SRSA was expressed as the $\mathrm{RC}_{50}$ value (Table 2). The $\mathrm{RC}_{50}$ value of the $80 \%$ ethanol extracts was the highest at $70.89 \pm 24.4 \mu \mathrm{g} / \mathrm{mL}$, followed by the $40 \%$ ethanol extracts $(73.90 \pm 6.31 \mu \mathrm{g} / \mathrm{mL}), 100 \%$ ethanol extracts $(87.19 \pm 1.37 \mu \mathrm{g} / \mathrm{mL}), 20 \%$ ethanol extracts $(88.44 \pm 7.69 \mu \mathrm{g} / \mathrm{mL})$, and distilled water extracts $(90.25 \pm 0.68 \mu \mathrm{g} / \mathrm{mL})$ in that order. From these results, all extracts of $S$. officinalis showed better scavenging activity than L-ascorbic acid, which showed a scavenging activity of 10 to $40 \%$ at 50 to $200 \mu \mathrm{g} / \mathrm{mL}$.

\section{Nitric Oxide radical ( $\mathrm{NO} \cdot$ ) scavenging activity}

$\mathrm{NO}$ can easily diffuse cell membranes and react with other reactive oxygen species. In particular, it readily reacts with $\mathrm{O}_{2}$ to produce peroxynitrite $\left(\mathrm{ONOO}^{-}\right)$, a highly reactive oxidizing agent (Lee \& Jeong, 2006). It is also said that mass-generated NO can further increase peroxynitrite production and cause cell and tissue damage, leading to aging and senile diseases (Jo \& Jeong, 2008). The NO radical scavenging activity of the extracts were all higher than that of BHA used as a positive control (Figure 1A). Among them, $80 \%$ ethanol extracts showed the highest activity, ranging from $83.98 \pm 0.53 \%$ to $92.04 \pm 0.54 \%$.

\subsection{Assay for the estimation of anti-wrinkling}

\section{Collagenase enzyme inhibition assay}

Collagen, along with elastin, is a key indicator material related to skin elasticity and wrinkles, and is known to occupy $90 \%$ of the skin dermis. Collagenase activity was increased by various factors such as ultraviolet rays or external environmental stress. Collagenase is known to cause skin aging by breaking down collagen causing wrinkles and loss of elasticity (Kim et al., 2018). All extracts of the S. officinalis had better collagenase enzyme inhibitory activity EGCG as a positive control. As the concentration increased, the collagenase enzyme inhibitory activity also increased (Figure 1B). The activity was the best in distilled water extracts, $21.11 \%$ to $46.32 \% ; 20 \%$ ethanol extracts, $32.09 \%$ to $53.58 \%$; $40 \%$ ethanol extracts, $23.53 \%$ to $48.64 \%$; and $80 \%$ ethanol extracts, $25.95 \%$ to $46.32 \%$, respectively. Among them, $80 \%$ ethanol extractsshowed the best collagenase enzyme inhibitory activity. These results were consistent with Jang et al. (2012) research that collagenase inhibitory activity of S. officinalis root fractions was effective.

\section{Elastase enzyme inhibition assay}

The occurrence of endogenous skin aging is another route of skin aging. Elastase is known to be the only enzyme that induces wrinkle formation by decomposing elastin in the stratum corneum to reduce skin elasticity (Hwang et al., 2016). All extracts of $S$. officinalis led to inhibition of elastase enzyme at concentrations of 50 to $400 \mu \mathrm{g} / \mathrm{mL}$ (Figure 1C) and these 

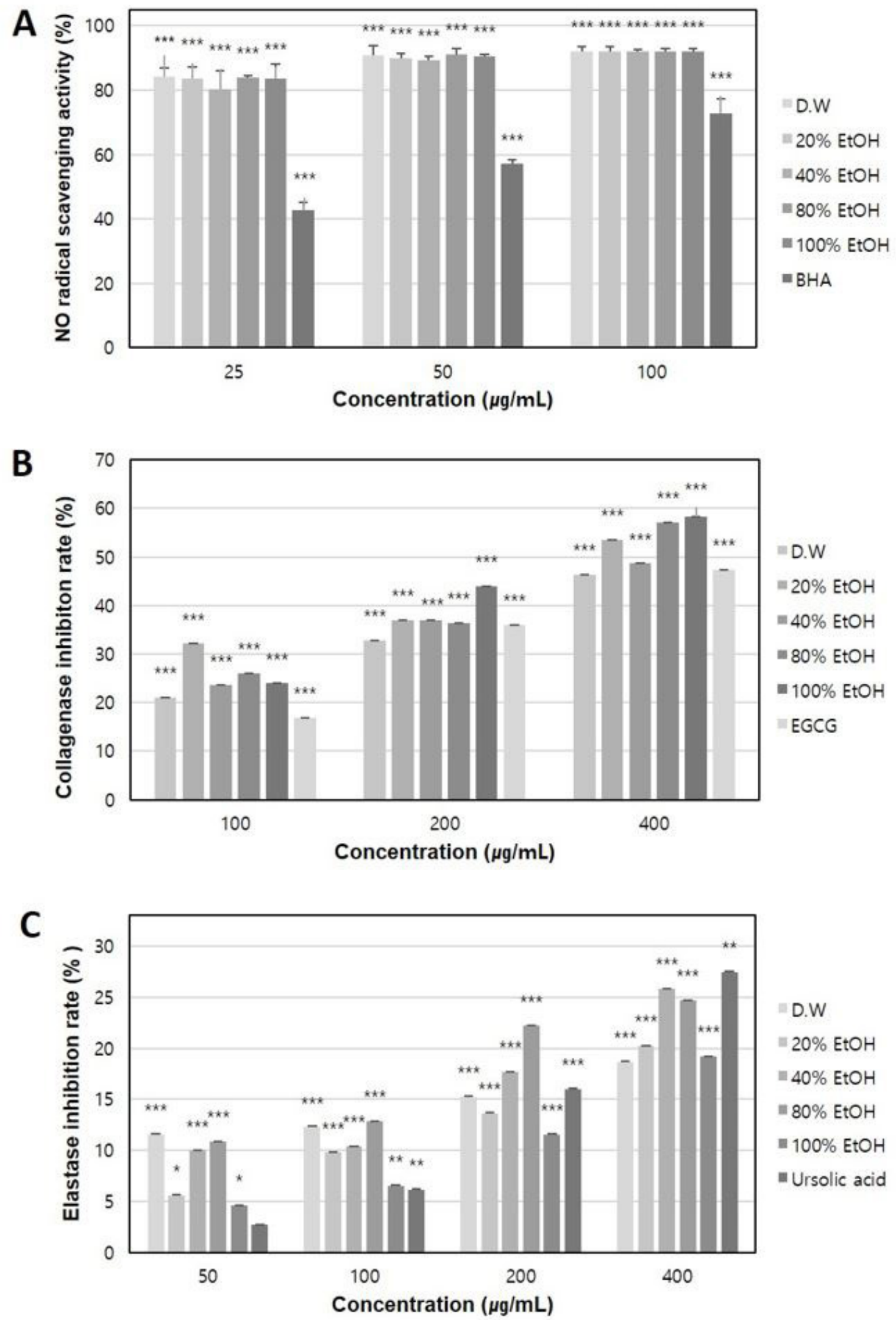

Figure 1. Effect of extracts from S. officinalis L. (A) NO radical scavenging activity; (B) Collagenase inhibition activity. Elastase inhibition activity. All the experiments were repeated three times. The values are indicated as mean \pm standard deviation of three independent experiments. ${ }^{* * *} \mathrm{p}<0.001$ significance for the comparison with the control. 
Antioxidant activities and anti-wrinkling effect of sanguisorba officinalis 1.

Table 3. Correlation coefficient between antioxidant, reactive nitrogen species and anti-wrinkle of extracts by Sanguisorba officinalis L. condition

\begin{tabular}{|c|c|c|c|c|c|c|c|c|c|c|}
\hline Factors & $\mathrm{TPC}^{1)}$ & $\mathrm{TFC}^{2)}$ & $\mathrm{TAC}^{3)}$ & FRAP $^{4)}$ & DPPH & ABTS & SARS $^{5)}$ & Elastase & Collagenase & $\mathrm{NO}^{6}$ \\
\hline TPC & 1 & $0.958^{* *}$ & $0.830^{* *}$ & $0.983^{* *}$ & -0.054 & 0.316 & -0.316 & -0.012 & -0.286 & -0.129 \\
\hline TFC & & 1 & $0.872^{* *}$ & $0.932^{* *}$ & -0.241 & 0.320 & -0.224 & 0.136 & -0.262 & -0.140 \\
\hline TAC & & & 1 & $0.822^{* *}$ & -0.120 & 0.140 & -0.053 & 0.230 & -0.142 & 0.035 \\
\hline DPPH & & & & & 1 & 0.282 & 0.152 & -0.240 & -0.046 & 0.212 \\
\hline ABTS & & & & & & 1 & -0.122 & -0.080 & -0.307 & -0.290 \\
\hline Collagenase & & & & & & & & & 1 & $0.450^{* *}$ \\
\hline $\mathrm{NO}$ & & & & & & & & & & 1 \\
\hline
\end{tabular}

${ }^{1)}$ Total polyphenol contents; ${ }^{2)}$ Total flavonoid contents; ${ }^{3)}$ Total antioxidant capacity; ${ }^{4)}$ Ferric-reducing antioxidant power; ${ }^{5}$ Superoxide anion radical scavenging activity; ${ }^{6} \mathrm{NO}$ radical scavenging activity; ${ }^{*} \mathrm{P}<0.05 ;{ }^{* *} \mathrm{P}<0.01$ (Pearson).
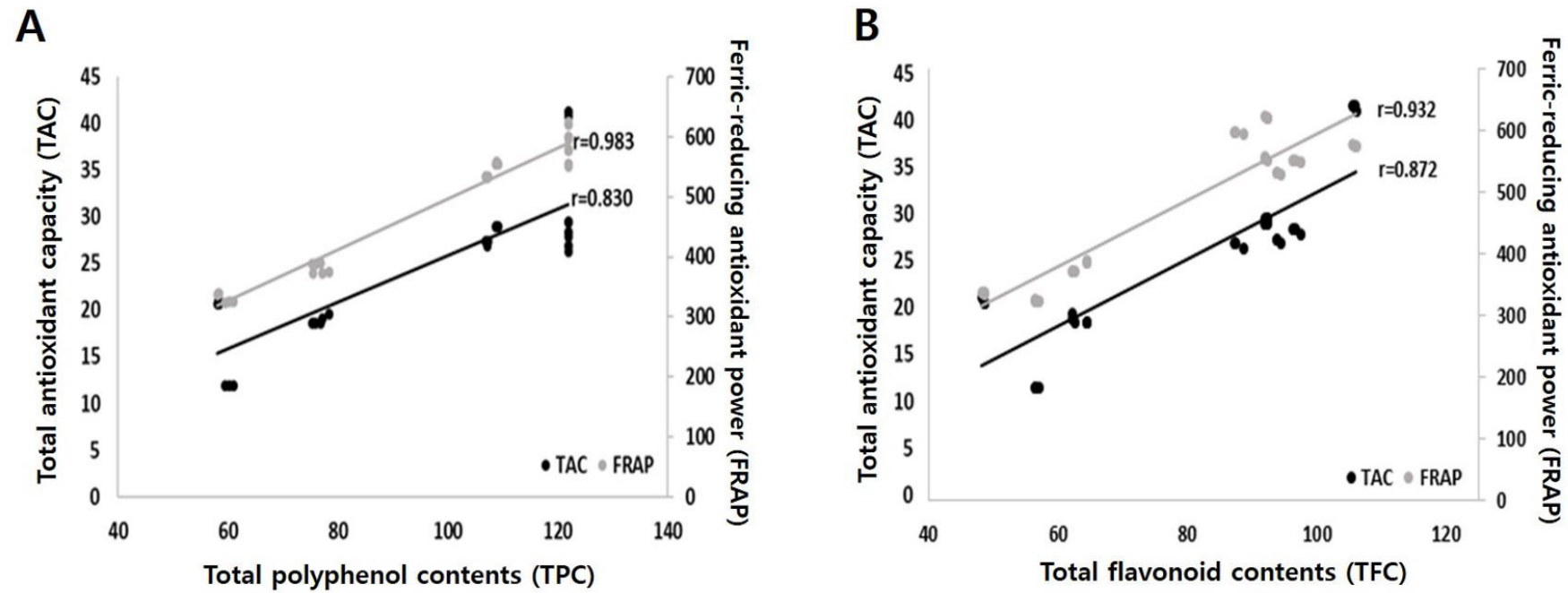

Figure 2. Correlation between antioxidant activity and anti-wrinkle of S. officinalis L. extracts. (A) Correlation between Total polyphenol contents and antioxidant capacity; (B) Correlation between Total flavonoid contents and antioxidant capacity. All the experiments were repeated three times.

results were in concentration-dependent manner and were better than the positive control of ursolic acid at concentrations of 50 to $100 \mu \mathrm{g} / \mathrm{mL}$. The best was $80 \%$ ethanol extracts showing $10.90 \pm 0.01 \%$ to $24.69 \pm 0.01 \%$.

\subsection{Correlation between antioxidant activity assay and anti- wrinkling}

Table 3 showed the results of analyzing the correlation between antioxidant and anti-aging in the samples. Depending on the ethanol concentrations of the S. officinalis extracts, total polyphenol contents showed high positive correlation with total antioxidant activity $(\mathrm{r}=0.830, \mathrm{p}<0.01)$ and FRAP $(\mathrm{r}=0.983$, $\mathrm{p}<0.01$ ) (Figure $2 \mathrm{~A}$ ), and flavonoids showed a high positive correlation with total antioxidant activity $(\mathrm{r}=0.872, \mathrm{p}<0.01)$ and FRAP $(\mathrm{r}=0.932, \mathrm{p}<0.01)$ (Figure $2 \mathrm{~B})$. These results were confirmed that the higher the concentrations of polyphenols and flavonoids, the higher the total antioxidant activity. For example, the polyphenol content and flavonoid content was the highest in $80 \%$ ethanol extracts, and total antioxidant activity were also the highest in $80 \%$ ethanol extracts at $121.96 \pm 0.00 \mathrm{mg} \mathrm{GAE} / \mathrm{g}$ and $101.19 \pm 2.87 \mathrm{mg} \mathrm{CE} / \mathrm{g}$, respectively (Table 1, Table 2).

Superoxide anion radical scavenging activity showed elastase inhibitory activity $(\mathrm{r}=0.421, \mathrm{p}<0.01)$, collagenase enzyme inhibitory activity $(\mathrm{r}=0.385, \mathrm{p}<0.05)$, and No radical scavenging activity $(\mathrm{r}=0.542, \mathrm{p}<0.01)$ (Table 3$)$. NO radical scavenging activity showed elastase inhibitory activity $(r=0.499$, $p<0.01)$ and collagenase enzyme inhibitory activity $(r=0.450$, $\mathrm{p}<0.01$ ) (Table 3).

\section{Conclusions}

To evaluate the physiological activity of $S$. officinalis and to confirm the correlations between the physiologically active substances, the extraction was performed using distilled water, $20 \%, 40 \%, 80 \%$, and $100 \%$ ethanol. Among them, the highest extraction yield were $80 \%$ and $100 \%$ ethanol extracts, which was judged to be economical as it showed an extraction yield of 
$10 \%$ or more. The total polyphenol contents and total flavonoid contents were the highest in the $80 \%$ ethanol extracts, and the total antioxidant activity (TAC) was also the best in the $80 \%$ ethanol extracts. The total antioxidant activity, polyphenol contents $(\mathrm{r}=0.830, \mathrm{p}<0.01)$, and flavonoid contents $(\mathrm{r}=0.872$, $\mathrm{p}<0.01$ ) were correlated with each other. In superoxide anion radical scavenging activity, $80 \%$ ethanol extracts had the highest. These results validated that the optimum extraction concentration for S. officinalis was $80 \%$ ethanol.

\section{Conflict of interest}

The authors declare that they have no conflict of interest.

\section{References}

Benzie, I. F., \& Strain, J. J. (1996). The ferric reducing ability of plasma (FRAP) as a measure of "antioxidant power": the FRAP assay. Analytical Biochemistry, 239(1), 70-76. http://dx.doi.org/10.1006/ abio.1996.0292. PMid:8660627.

Boo, H. O., Lee, H. H., Lee, J. W., Hwang, S. J., \& Park, S. U. (2009). Different of total phenolics and flavonoids, radical scavenging activities and nitrite scavenging effects of Momordica charantia L. according to cultivars. Korean Journal of Medicinal Crop Science, 17, 15-20.

Cho, S. H., Choi, Y. J., Rho, C. W., Choi, C. Y., Kim, D. S., \& Cho, S. H. (2008). Reactive oxygen species and cytotoxicity of Bamboo (Phyllostachys pubescens) Sap. Korean Journal of Food Preservation, 15, 105-110.

Choi, S. I., Lee, Y. M., \& Heo, T. R. (2003). Screening of hyaluronidase inhibitory and free radical scavenging activity in vitro of traditional herbal medicine extracts. The Korean Society For Biotechnology And Bioengineering, 18, 282-288.

Fridovich, I. (1970). Quantitative aspects of the production of superoxide anion radical by milk xanthin oxidase. The Journal of Biological Chemistry, 245(16), 4053-4057. http://dx.doi.org/10.1016/S00219258(18)62884-4. PMid:5496991.

Halliwell, B., Gutteridge, J. M. C., \& Cross, C. E. (1992). Free radicals, antioxidants, and human disease: where are we now? The Journal of Laboratory and Clinical Medicine, 119(6), 598-620. PMid:1593209.

Ham, H. N., Chandra, S. A., Kim, J. E., Lee, T. B., Yoo, B. W., Kim, M. S., Kim, K. S., Cha, J. S., Lee, Y. M., Kim, J. Y., \& Leem, J. Y. (2018). Simultaneous analysis of the compounds of natural cosmetic resources containing chrysanthemum zawadskii, Perilla frutescens, Rosa multiflora and their anti-oxiativeactivity. Korean Journal of Pharmacognosy, 49, 312-321.

Hwang, J. Y., Cho, H. Y., \& Pyo, Y. H. (2016). Effect of unpolished rice vinegar containing monascus-fermented soybean on inhibitory activities of tyrosinase and elastase. Journal of the Korean Society of Food Science and Nutrition, 45(1), 149-154. http://dx.doi.org/10.3746/ jkfn.2016.45.1.149.

Jang, Y. A., Kim, Y. H., Shin, J. C., Han, S. I., \& Lee, J. T. (2013). The study on pharmacologic activation as cosmetic material of Sanguisorbae radix. The Korea Journal of Herbology, 28(5), 79-85. http://dx.doi. org/10.6116/kjh.2013.28.5.79.

Jang, Y. A., Yeo, S. I., \& Lee, J. T. (2012). The research of pharmacological activation for Sanguisorbae radix fractions as cosmetic material. The Korea Journal of Herbology, 27(2), 43-46. http://dx.doi.org/10.6116/ kjh.2012.27.2.43.
Jo, E. Y., \& Jeong, J. C. (2008). The inhibitory effects of Ulmus davidiana on the reactive species and proinflammatory proteins. The Korean Journal of Internal Medicine, 29, 421-431.

Kil, K. J., Doh, E. S., Chang, J. P., Lee, S. H., \& Yoo, J. H. (2015). Antibacterial and antioxidant activities of bio-fermented Sanguisorbae radix extract. The Korea Journal of Herbology, 30(4), 29-35. http:// dx.doi.org/10.6116/kjh.2015.30.4.29..

Kim, C. J., Shim, J. K., Kwon, K. C., Lim, J. D., Choi, S. K., Yu, C. Y., \& Lee, J. G. (2018). Changes in non-saponin fatty acid content and increases in inhibitory activities of collagenase and elastase by treatment with Saccharomyces cerevisiae of the supercritical fluid extracted oil of the adventitious roots culture of wild mountain ginseng. Korean Journal of Medicinal Crop Science, 26(2), 170-180. http://dx.doi.org/10.7783/KJMCS.2018.26.2.170.

Kim, E. J., Choi, J. Y., Yu, M. R., Kim, M. Y., Lee, S. H., \& Lee, B. H. (2012). Total polyphenols, total flavonoid contents, and antioxidant activity of Korean natural and medicinal plants. Kor. Journal of Food Science and Technology, 44, 337-342.

Kim, H. H., Heo, M. R., Lee, S. M., \& Yim, S. H. (2019). Validation of analytical method and antioxidant properties of Eriobotrya Japonica Lindl. Leaf extract according to extraction solvent. Kor. Journal of Food Science and Technology, 51, 301-308.

Kim, S. R., Won, J. H., \& Kim, M. R. (2011) Antimicrobial activity against food hazardous microorganisms and antimutagenicity against Salmonella serotype Typhimurium TA100 of an ethanol extract from Sanguisorba officinalis L. Korean Journal of Food and Cookery Science, 27, 17-26.

Kim, Y. D., Mahinda, S., Koh, K. S., Jeon, Y. J., \& Kim, S. H. (2009). Reactive oxygen species scavenging activity of Jeju native citrus peel during maturation. Journal of the Korean Society of Food Science and Nutrition, 38, 462-469.

Kraunsoe, J. A., Claridge, T. D., \& Lowe, G. (1996). Inhibition of human leukocyte and porcine pancreatic elastase by homologues of bovine pancreatic trypsin inhibitor. Biochemistry, 35(28), 9090-9096. http:// dx.doi.org/10.1021/bi953013b. PMid:8703913.

Ku, K. M., Kim, H. S., Kim, B. S., \& Kang, Y. H. (2009). Antioxidant activities and antioxidant constituents of pepper leaves from various cultivars and correlation between antioxidant activities and antioxidant constituents. Journal of Applied Biological Chemistry, 52(2), 70-76. http://dx.doi.org/10.3839/jabc.2009.013.

Lee, D. J., \& Jeong, J. C. (2006). Peroxynitrites cavenging activity of Samjunghwan. The Korean Journal of Internal Medicine, 27, 178-187.

Lee, G. Y., \& Im, D. Y. (2012). Skin-related biological activities of the extract and its fractions from Puerarariae Flos. Journal of Society of Cosmetic Scientists of Korea, 18, 858-864.

Lee, H. J., Choi, J. I., \& Choi, S. J. (2012). Physiological activities and amino acid compositions of Korean dried laver porphyra products. Korean Journal of Fisheries and Aquatic Sciences, 45, 409-413.

Lim, S. M. (2010). Resistance to reactive oxygen species and antioxidant activities of some strains of lactic acid bacteria from the mustard leaf kimchi. Korean Journal of Microbiology, 46, 375-382.

Moreno, M. I. N., Isla, M. I., Sampietro, A. R., \& Vattuone, M. A. (2000). Comparison of the free radical-scavenging activity of propolis from several regions of Argentina. Journal of Ethnopharmacology, 71(12), 109-114. http://dx.doi.org/10.1016/S0378-8741(99)00189-0. PMid:10904153.

Nagata, N., Momose, K., \& Ishida, Y. (1999). Inhibitory effects of catecholamines and anti-oxidants on the fluorescence reaction of 4,5-diaminofluorescein, DAF-2, a novel indicator of nitric oxide. 
Journal of Biochemistry, 125(4), 658-661. http://dx.doi.org/10.1093/ oxfordjournals.jbchem.a022333. PMid:10101276.

Park, G. H., Lee, J. T., \& An, B. J. (2012a). Anti-microbial effect on Streptococcus mutans and anti-oxidant effect of the butanol fractions of Sanguisorbae Radix. The Korea Journal of Herbology, 27(3), 23-29. http://dx.doi.org/10.6116/kjh.2012.27.3.23.

Park, H. J., Kang, S. A., Lee, J. Y., \& Cho, Y. J. (2012b). Antioxidant activities of extracts from medicinal plants. Korean Journal of Food Preservation, 19(5), 744-750. http://dx.doi.org/10.11002/ kjfp.2012.19.5.744.

Park, S. H., Lim, H. Y., \& Han, J. H. (2003). A study of medicinal herbs for functional food application-(I) nutritional composition and scolpectin analysis of Artemisia capillaries. The East Asian Society Of Dietary Life, 13, 552-560.

Prieto, P., Pineda, M., \& Aguilar, M. (1999). Spectrophotometric quantitation of antioxidant capacity through the formation of a [phosphomolybdenum complex: specific application to the determination of Vitamin E. Analytical Biochemistry, 269(2), 337341. http://dx.doi.org/10.1006/abio.1999.4019. PMid:10222007.

Saha, M. R., Hasan, S. M. R., Akter, R., Hossain, M. M., Alam, M. S., Alam, M. A., \& Mazumder, M. E. H. (2008). In vitro free radical scavenging activity of methanol extract of leaves of Mimusops elegilinn. Bangladesh Journal of Veterinary Medicine, 6(2), 197-202. http://dx.doi.org/10.3329/bjvm.v6i2.2336.
Thaipong, K., Boonprakob, U., Crosby, K., Cisneros-Zevallos, L., \& Hawkins, B. D. (2006). Comparison of ABTS, DPPH, FRAP, and ORAC assays for estimating antioxidant activity from guava fruit extracts. Journal of Food Composition and Analysis, 19(6-7), 669-675. http://dx.doi.org/10.1016/j.jfca.2006.01.003.

Thannickal, V. J., \& Fanburg, B. L. (2000). Reactive oxygen species in cell signaling. American Journal of Physiology. Lung Cellular and Molecular Physiology, 279(6), L1005-L1028. http://dx.doi.org/10.1152/ ajplung.2000.279.6.L1005. PMid:11076791.

Wünsch, E., \& Heidrich, H. G. (1963). Zur quantitativen bestximmung der kollagenase. Hoppe-Seyler's Zeitschrift für Physiologische Chemie, 333, 149-151. http://dx.doi.org/10.1515/bchm2.1963.333.1.149. PMid:14058277.

Yamaguchi, T., Takamura, H., Matoba, T., \& Terao, J. (1998). HPLC method for evaluation of the free radical-scavenging activity of foods by using 1,1-diphenyl-2-picrylhydrazyl. Bioscience, Biotechnology, and Biochemistry, 62(6), 1201-1204. http://dx.doi.org/10.1271/ bbb.62.1201. PMid:9692204.

Yun, H. Y., Lim, S. J., Park, H. J., \& Shin, Y. G. (2018). Correlation between antioxidant compounds and activities of 'Hibiscus sabdariffa' teas from different origins. The East Asian Society Of Dietary Life, 28(1), 40-46. 